\title{
Ratlarda Parasetamol ile Oluşturulan Hepatotoksisite Üzerine Taraxacum officinale Etanol Ekstraktının Etkisi**
}

\author{
Esra AKTAŞ ŞENOCAK, Betül APAYDIN YILDIRIM*
}

Atatürk Üniversitesi, Veteriner Fakültesi, Biyokimya Anabilim Dalı, Erzurum, Türkiye.

Geliș Tarihi: 20.10.2016

Kabul Tarihi: 26.12.2016

\begin{abstract}
Özet: Ratlarda parasetamol ile oluşturulan hepatotoksisite üzerine Taraxacum officinale etanol ekstraktının kan ve karaciğer dokusundaki bazı biyokimyasal parametrelere ve karaciğer dokusunun histopatolojisi üzerine etkileri araştırıldı. Bu çalışmada, 5 aylık yaşta 36 adet Sprague Dawley rat kullanıldı. Sprague Dawley ratlar rastgele her grupta 6 rat olacak şekilde 6 gruba ayrıldı. Parasetamol (PARA) verilecek gruplardaki hayvanlar 24 saat aç bırakılıp ekstrakt verildikten 1 saat sonra 2 g/kg oral olarak (p.o.) PARA verildi. 1.Grup (Kontrol Grubu), \%5'lik DMSO intraperitoneal (i.p.), 2.Grup (TOE1 Grubu), 200 $\mathrm{mg} / \mathrm{kg} /$ gün/i.p. Taraxacum officinale ekstraktı (TOE) \%5'lik DMSO'da çözülerek i.p, 3.Grup (TOE2 Grubu), 250 $\mathrm{mg} / \mathrm{kg} / \mathrm{gün} / \mathrm{i}$. . . Taraxacum officinale ekstraktı, 4.Grup (PARA Grubu), 2 g/kg/p.o. Parasetamol, 5.Grup (PTOE1 Grubu), Parasetamol 2 g/kg/gün/p.o. + TOE 200 mg/kg/gün/i.p, 6.Grup (PTOE2 Grubu), Parasetamol 2 g/kg/gün/p.o. + TOE 250 $\mathrm{mg} / \mathrm{kg} / \mathrm{gün} / \mathrm{i} . \mathrm{p} 8$ gün boyunca uygulandı. Çalışma sonunda ratlardan alınan kan ve karaciğer dokusundan biyokimyasal ve histopatolojik analizler yapıldı. Parasetamol grubunda plazma AST, ALT, ALP, MDA, CAT ve nitrit düzeyleri; karaciğer MDA, nitrit ve nitrat düzeyleri kontrol grubuna göre artarken $(P<0.001)$; plazma GSH $(P<0.001)$, SOD $(P<0.001)$ ve GPx $(P<0.05)$ düzeyleri; karaciğer $\mathrm{GSH}$, CAT ve SOD $(\mathrm{P}<0.001)$ düzeyleri anlamlı olarak azaldı. Parasetamolün ratlarda oluşturduğu hepatotoksisiteyi Taraxacum officinale bitkisinin toprak üstü aksamlarından yapılan etanol ekstraktının $200 \mathrm{mg} / \mathrm{kg}$ uygulanan miktarının hepatotoksisiteyi anlamlı olarak azalttığı ve lipid peroksidasyonu önlediği, TOE $250 \mathrm{mg} / \mathrm{kg}$ uygulanan hayvanlarda toksik etki yaptığı tespit edildi. Elde edilen ekstraktın hepatotoksisite üzerine ve plazma ve karaciğer biyokimyasal parametreleri üzerine olumlu etkilerinin olduğu saptansa bile karaciğerde oluşan hasarı düzeltmek için zamana gereksinim duyulduğu kanaatine varıldı.
\end{abstract}

Anahtar Kelimeler: Antioksidan, Ekstrakt, Lipid peroksidasyonu, Parasetamol, Taraxacum officinale.

The Effect of Taraxacum officinale Ethanol Extract on Paracetamol Induced Hepatotoxicity in

Rats

\begin{abstract}
In this study was investigated on the effects on the some biochemical and histopathological parameters in plasma and liver tissue of Taraxacum officinale ethanol extract of paracetamol induced hepatotoxicity in rats. In this study was utilized 36 Sprague Dawley male rats, aged 5 months. Rats were divided 6 groups of 6 rats each, randomly. Animals of paracetamol administered were fasted 24 hour and $2 \mathrm{~g} / \mathrm{kg}$ peros (p.o) Paracetamol was given after the 1 hour extract was given. 1.Group Control 5\% DMSO intraperitoneal (i.p), 2. Group TOE1 $200 \mathrm{mg} / \mathrm{kg} /$ day/i.p. Taraxacum officinale extract (TOE) was dissolved in 5\% DMSO in distilled water, i.p., 3. Group TOE2 $250 \mathrm{mg} / \mathrm{kg} /$ day/i.p. Taraxacum officinale extract, 4. Group PARA 2 g/kg/p.o. Paracetamol, 5. Group PTOE1; Paracetamol 2 g/kg/day/p.o.+ TOE 200 mg/kg/day/i.p, 6. Group PTOE2 Paracetamol $2 \mathrm{~g} / \mathrm{kg} / \mathrm{day} / \mathrm{p}$. o.+ TOE $250 \mathrm{mg} / \mathrm{kg} / \mathrm{day} / \mathrm{i} . \mathrm{p}$ were administered for 8 day. At the end of the study biochemical and histopatological analyses were made from sample of blood and liver tissue. Plasma AST, ALT, ALP, MDA, CAT and Nitrite levels; liver tissue Nitrite and Nitrate levels were increased $(P<0.001)$; plasma GSH $(P<0.001)$, SOD $(P<0.001)$ and GPx levels $(P<0.05)$; liver tissue GSH, CAT, and SOD levels $(P<0.001)$ were decreased significantly in paracetamol group compared with control group. Paracetamol in rats formed hepatotoxicity Taraxacum officinale Wig. aerial part made from ethanol as extract is used TOE $100 \mathrm{mg} / \mathrm{kg}$ of the amount of hepatotoxicity significantly decreased and prevented lipid peroxidation. Toxic effect was determined in animals administered TOE $250 \mathrm{mg} / \mathrm{kg}$. Even if the obtained extract had positive effects on hepatotoxicity and biochemical parameters in liver and plasma, it was concluded that it was needed to for repair the damage of the liver.

Keywords: Antioxidant, Extract, Lipid peroxidation, Paracetamol, Taraxacum officinale.
\end{abstract}

\section{Giriş}

Türkçe adı Karahindiba olan Taraxacum officinale papatyagiller (Asteraceae) familyasının bir üyesidir. Daha çok kuzey yarım kürede özellikle Avrupa ve Asya'nın ılıman bölgelerinde sıkça rastlanan bir türdür. Türkiye'de ise çoğunlukla
Nisan-Mayıs aylarında, çayırlarda, yol kenarlarında yetişebilen çok yıllık sarı renkte çiçekleri olan bir bitkidir. Taraxacum officinale (KarahindibaDandelion) içerdiği terpenoid, sterol, kalsiyum, potasyum, vitamin A, nikotinik asit ve vitamin C gibi 
birçok önemli bileşiği içeren, besleyici değere sahip olan ve sıkça rastlanan bir bitkidir (Davis, 1965; Koç, 2002). Bu özelliklerinden dolayı özellikle karaciğer ve safra kesesi hastalıklarında taze olarak 5-6 tane çiçek sapının yenmesi kronik karaciğer iltihaplarında ve karaciğer yağlanmasında iyileşme sağlayarak safra kesesinin çalışmalarını düzenlediği ifade edilmiştir. Bununla beraber şeker hastalığı, cilt hastalıkları, vitamin eksikliği, damar sertliği, kan şekerini düşürmede, iştah açılmasında, kanın temizlenmesinde, kansızlıkta, romatizma ve gut hastalıklarında, kemik bütünlüğünün korunmasında, mide sıvılarını düzene sokarak mideyi atık maddelerden temizlemede ve bazı kanser türlerinde büyük etkiye sahip olmasına rağmen pek çok kişi tarafından tanınmayıp zararlı bir ot olarak bilinir (Anonim, 2013a; Anonim, 2013b; Fortea ve ark., 2009; Koç, 2002). Karahindiba'nın bileşimindeki seskiterpen laktonlar ve fenil propanoid sayesinde anti-inflamasyon etkisinin olduğu bilinmektedir. Aynı zamanda barındırdığı terpenler, polisakkarit bileşenleri; bağışıklık sistemini düzenleyici, trombosit birikimini önleyici ve karaciğer koruyucu etkilere sahiptir (Adam, 2012; Sigstedt ve ark., 2008). B, C, D, E vitaminlerinin yanı sıra kolin, inozitol, lesitin, mineraller ve oligoelementleri (kalsiyum, sodyum, magnezyum, demir, bakır, fosfor, çinko, manganez) bulundurması açısından oldukça önemli bir bitkidir. Ayrıca besleyici değeri olan Karahindiba, yüksek oranda potasyum içermesinden dolayı en iyi doğal potasyum kaynaklarından biridir (Gallaher ve ark., 2006).

Taraxacum officinale (karahindiba) bitkisini içeren yapraklı sebzelerle oluşturulan karışımın plazma, karaciğer, kalp ve böbrekte faydalarıyla birlikte antioksidan seviyeleri (glutatyon ve $\beta$ karoten) ve antioksidan enzimlerinin aktivitelerini (süperoksit dismutaz, peroksidaz, redükte glutatyon) farelerde arttırdığı ayrıca lipid peroksidasyonunu da anlamlı olarak azalttığı görülür. Taraxacum officinale'nin özellikle kök ve yapraklarının ratlara uygulanmasıyla endojen antioksidan profilinde gelişim gözlenir (Champe ve ark., 2007; Kuntz ve Kuntz, 2008). Parasetamol (Asetaminofen-APAP), 1950 yılından beri sıklıkla kullanılan analjezik ve antipiretik özelliklere sahip ilaçlardan biridir (Kayaalp, 2005). Parasetamolün aşırı dozda alınmasıyla sitokrom p-450 mikrozomal enzimleri aracılığıyla reaktif ara ürün olan NAPQI (Nasetilbenzokinonimin)'nın derişiminin artmasıyla hepatik nekroza ve ileri durumlarında da karaciğer yetmezliğine neden olduğu görülür (Jaeschke ve Bajt, 2006). NAPQI'nın birikmesi vücuttaki serbest GSH'ın bağlanmasını sağlayarak hücrede var olan GSH'ı tüketir bu da hücrede oksidatif stresin oluşumuna yol açar. NAPQI sülfhidril (-SH) gruplarını okside etmesine neden olup $\mathrm{Ca}^{++}$konsantrasyonu- nun artmasına ayrıca NAPQI hücre içi proteinlerini yok ederek hücrenin ölümüne yol açar (Rang ve ark., 2011).

Bu çalışmada; Taraxacum officinale bitki ekstraktının hepatoprotektif ve antioksidan özelliklerini araştırmak üzere, kanda AST (Aspartat transaminaz), ALT (Alanin transaminaz), ALP (Alkalen Fosfataz) düzeyleri ile MDA (Malondialdehid), GSH (Glutatyon), CAT (Katalaz), SOD (Süperoksit dismutaz), GPx (Glutatyon peroksidaz), Nitrit, Nitrat ve karaciğer dokusundaki MDA, GSH, CAT, SOD, GPX, Nitrit, Nitrat düzeyleri ile birlikte karaciğer dokusunun histopatolojik muayenesiyle parasetamol ile oluşturulan deneysel hepatotoksisite üzerindeki koruyucu etkinliğinin araştırılması amaçlandı.

\section{Materyal ve Metot}

Hayvan materyali: Çalışma için kullanılan ratlar Atatürk Üniversitesi'ne bağlı Tıbbi Deneysel Uygulama ve Araştırma Merkezi (ATADEM) tarafından sağlanmış olup 25.03.2013 tarih ve 36643897-475 sayılı yazı ile gereken etik kurul belgesi ile onaylanmıştır. Araştırma için 5 (beş) aylık olan 36 adet Sprague-Dawley cinsi rat kullanıldı. Canlı ağırlıkları 250-300 g olan ratlar 12 saat aydınlık / karanlık döngüsünde $22 \pm 2{ }^{\circ} \mathrm{C}$ oda sıcaklığında tutuldular. Bir hafta süreyle ortama adaptasyonları sağlanan ratlar çalışma boyunca standart rat yemi ve musluk suyu ile ad libitum beslendiler.

Taraxacum officinale ekstraktı: Araştırmada kullanılan Karahindiba bitkisi çiçekli dönemde toprak üstü aksanı toplanarak gölgede kurutuldu. Daha sonra bu bitki öğütülerek, Atatürk Üniversitesi Ziraat Fakültesi Uçucu Yağ Laboratuvarında 48 saat süre ile etil alkolde bekletilip süzüldü. Rotary evaporatör yardımıyla çözücünün uzaklaştırılmasının ardından ekstreler, $+4{ }^{\circ} \mathrm{C}$ 'de buzdolabında muhafaza edildi (Kordali ve ark., 2009).

Parasetamol materyali: Ratlarda toksisite oluşturmak amacıyla kullanılan parasetamol, piyasadan temin edilip, $2 \mathrm{~g} / \mathrm{kg}$ Parasetamol ; \%1'lik karboksimetilselüloz (CMC), 1xPBS tamponunda çözüldü ve ratlara oral yolla 2 cc uygulandı (Albayrak, 2013).

Deneysel uygulamalar: Ratlar rastgele her grupta 6 rat olacak şekilde 6 gruba ayrıldı. Parasetamol verilecek gruplardaki hayvanlar 24 saat aç bırakılıp ekstrakt verildikten 1 saat sonra $2 \mathrm{~g} / \mathrm{kg}$ p.o. parasetamol verildi. 1. Grup Kontrol grubu $\% 5^{\prime}$ lik DMSO i.p, 2. Grup TOE1 grubu 200 mg/kg/gün/i.p. Taraxacum officinale ekstraktı \%5'lik DMSO'da çözülerek i.p, 3. Grup TOE2 grubu 250 
mg/kg/gün/i.p. Taraxacum officinale ekstraktı, 4. Grup PARA Grubu, 2 g/kg/p.o. Parasetamol, 5. Grup PTOE1 grubu Parasetamol 2 g/kg/gün/p.o.+TOE 200 $\mathrm{mg} / \mathrm{kg} /$ gün/i.p, 6. Grup PTOE2 grubu Parasetamol 2 g/kg/gün/p.o.+TOE 250 mg/kg/gün/i.p 8 gün boyunca uygulandı. Çalışma sonunda ratlardan alınan kan ve karaciğer dokusunda biyokimyasal ve histopatolojik analizler yapıldı. Alınan kan lityum heparinli tüplere aktarılarak, $3000 \mathrm{rpm}$ 'de, $+4{ }^{\circ} \mathrm{C}^{\prime} \mathrm{de} 10 \mathrm{dk}$ santrifüj edilerek plazmaları ayrıldı alınan dokuların bir kısmıyla beraber biyokimyasal analizler yapılıncaya kadar $-20{ }^{\circ} \mathrm{C}^{\prime}$ de deep freezde saklandı. Ratlardan elde edilen karaciğer dokuları 1/10 oranında $0.1 \mathrm{M}, \mathrm{pH} 7.4$ fosfat tamponu ile homojenize edilerek $1700 x g$ 'de santrifüj edildikten sonra süpernatantlar deney için kullanıldı. Alınan karaciğerin diğer bir kısmı \%10'luk formalin içine konulup histopatolojik analizler yapılıncaya kadar saklandı.

Biyokimyasal analizler: AST, ALT, ALP tayinleri için analizde TML ticari kiti kullanıldı. Plazmada MDA (Yoshioka ve ark., 1979), GSH (Tietze, 1969); plazma ve karaciğer dokusunda CAT (Goth, 1991), SOD (Sun ve ark., 1988), GPx (Matkovics ve ark., 1988); karaciğer dokusunda MDA (Placer ve ark., 1966), GSH (Ball, 1996; Fernandez ve Videla, 1981) ve Nitrit ve Nitrat (Stahr, 1977) düzeyleri spektrofotometrik olarak ölçüldü (Biotechepocha UV-Visible EIA Spektrofotometre).

Histopatolojik analizler: Histopatolojik değerlendirme amacıyla alınan karaciğer dokuları \%10'luk formalin solüsyonunda 24 saat tespit edildikten sonra, akan çeşme suyunda 10 saat yıkandı. Rutin doku takibinde alkol $\left(70^{\circ}, 80^{\circ}, 90^{\circ}, 96^{\circ}\right.$ ve $\left.100^{\circ}\right)$ ve ksilol serilerinden geçtikten sonra parafinde bloklara gömüldü. Her bloktan $4 \mu \mathrm{m}$ kalınlığında kesitler alınıp lam üzerinde preparatlar hazırlandı. Histopatolojik inceleme için hazırlanan preparatlar Hematoksilen-Eozin (H\&E) ile boyanıp ışık mikroskobu ile incelendi.

İstatistiksel analizler: Tüm gruplar arasındaki farklılı̆ın önemi için SPSS 11.5 paket programı kullanılarak varyans analizi, çoklu karşılaştırma için Duncan testi yapıldı (Sümbüloğlu ve Sümbüloğlu, 1998).

\section{Bulgular}

Biyokimyasal bulgular: Parasetamol ile oluşturulan hepatotoksisite ve TOE uygulanan grupların plazmalarındaki AST, ALT, ALP, MDA, GSH, CAT, $\mathrm{SOD}, \mathrm{GPx}$, Nitrit ve Nitrat; karaciğer dokularındaki MDA, GSH, CAT, SOD, GPx, Nitrit ve Nitrat düzeyleri Tablo 1'de ve Tablo 2'de gösterildi. Plazma AST, ALT, ALP ve MDA düzeyleri karaciğer toksisitesiyle beraber istatistiksel olarak anlamlı derecede artış $(\mathrm{P}<0.001)$, PTOE1 grubunda ise bu parametrelerde parasetamol grubuna göre anlamlı oranda azalma tespit edildi $(P<0.001)$. Kontrol grubuna göre TOE2 ve PARA grubundaki GSH düzeyinde azalma saptandı $(P<0.01)$. Plazma katalaz düzeylerinde özellikle bitki uygulanan gruplarda kontrol grubuna göre bir artış saptandı $(P<0.001)$. Plazma SOD $(P<0.001), G P x \quad(P<0.05)$ düzeyi kontrol grubuna göre PARA grubunda anlamlı olarak azalırken diğer gruplarda anlamlı olarak arttı. Nitrit düzeyinde kontrol gruba göre TOE ve PARA gruplarında genel olarak bir artış söz konusu oldu $(\mathrm{P}<0.001)$. Nitrat düzeyinde istatistiksel olarak anlam saptanmadı $(\mathrm{P}>0.05)$.

Tablo 1. Kontrol grubu ile TOE1, TOE2,PARA,PTOE1, PTOE2 gruplarının plazmasındaki bazı biyokimyasal parametreler (X \pm Sx, n:6)

\begin{tabular}{|c|c|c|c|c|c|c|c|}
\hline & \multicolumn{7}{|c|}{ Gruplar } \\
\hline & Kontrol & TOE1 & TOE2 & PARA & PTOE1 & PTOE2 & $\mathbf{P}$ \\
\hline AST (U/L) & $52.25 \pm 1.95^{b c}$ & $47.67 \pm 1.567^{c}$ & $57.08 \pm 0.57^{\mathrm{bc}}$ & $167.10 \pm 22.23^{a}$ & $80.32 \pm 2.18^{b}$ & $184.83 \pm 2.99^{\mathrm{a}}$ & $* * *$ \\
\hline ALT (U/L) & $44.80 \pm 1.43^{\mathrm{e}}$ & $43.35 \pm 2.05^{e}$ & $54.56 \pm 0.61^{d}$ & $133.47 \pm 0.45^{a}$ & $77.18 \pm 0.82^{c}$ & $127.59 \pm 0.76^{b}$ & $* * *$ \\
\hline ALP (U/L) & $44.73 \pm 2.15^{\mathrm{e}}$ & $42.91 \pm 2.18^{e}$ & $49.65 \pm 0.12^{d}$ & $129.27 \pm 0.43^{a}$ & $68.47 \pm 0.68^{c}$ & $119.29 \pm 0.27^{b}$ & $* * *$ \\
\hline MDA (mmol/L) & $10.92 \pm 0.45^{c}$ & $10.30 \pm 0.28^{c}$ & $11.17 \pm 0.22^{\mathrm{c}}$ & $15.27 \pm 1.19^{b}$ & $10.42 \pm 0.16^{c}$ & $19.20 \pm 0.72^{\mathrm{a}}$ & $* * *$ \\
\hline GSH (mmol/L) & $0.23 \pm 0.01^{a}$ & $0.22 \pm 0.01^{\mathrm{ab}}$ & $0.17 \pm 0.01^{c}$ & $0.19 \pm 0.02^{\mathrm{bc}}$ & $0.20 \pm 0.01^{\mathrm{ab}}$ & $0.22 \pm 0.01^{\mathrm{ab}}$ & $* *$ \\
\hline CAT (kU/L) & $243.78 \pm 11.52^{c}$ & $432.31 \pm 20.17^{\mathrm{ab}}$ & $464.58 \pm 26.46^{a}$ & $379.16 \pm 25.91^{b}$ & $449.44 \pm 6.81^{\mathrm{a}}$ & $453.19 \pm 1.72^{\mathrm{a}}$ & $* * *$ \\
\hline SOD (U/mL) & $13.69 \pm 0.13^{a}$ & $13.96 \pm 0.10^{\mathrm{a}}$ & $13.83 \pm 0.14^{\mathrm{a}}$ & $12.88 \pm 0.27^{b}$ & $13.96 \pm 0.14^{\mathrm{a}}$ & $14.12 \pm 0.16^{a}$ & $* * *$ \\
\hline GPX (U/mL) & $5.89 \pm 0.12^{\mathrm{ab}}$ & $5.94 \pm 0.18^{\mathrm{ab}}$ & $5.93 \pm 0.18^{\mathrm{ab}}$ & $5.49 \pm 0.10^{b}$ & $6.43 \pm 0.45^{a}$ & $5.86 \pm 0.19^{a b}$ & $*$ \\
\hline NіTRіT (ppm) & $0.44 \pm 0.02^{c}$ & $0.45 \pm 0.01^{c}$ & $0.82 \pm 0.14^{b}$ & $1.26 \pm 0.02^{\mathrm{a}}$ & $0.60 \pm 0.04^{c}$ & $0.55 \pm 0.04^{c}$ & $* * *$ \\
\hline NITRAT (ppm) & $10.59 \pm 0.26$ & $9.89 \pm 0.15$ & $10.93 \pm 0.34$ & $10.95 \pm 0.39$ & $10.23 \pm 0.20$ & $10.47 \pm 0.28$ & Ös \\
\hline
\end{tabular}

ÖS: $\mathrm{P}>0.05 * \mathrm{P}<0.05,{ }^{*} \mathrm{P}<0.01,{ }^{* * *} \mathrm{P}<0.001$ ve $\mathrm{a}, \mathrm{b}, \mathrm{c}, \mathrm{d}$, e: Aynı satırda farklı harfle gösterilen ortalamalar arası fark önemlidir ( $\left.<<0.05\right)$

Karaciğer MDA düzeyi kontrol grubuna göre TOE1 ve TOE2 gruplarında anlamlı olarak arttı, PARA grubuna göre PTOE1 ve PTOE2 gruplarında istatistiksel olarak anlamlı azalma saptandı 
$(P<0.001)$. GSH düzeyi TOE1, PARA, PTOE1 gruplarında kontrol grubu karşılaştırıldığında bu gruplarda azaldı $(\mathrm{P}<0.001)$; TOE2, PTOE2 gruplarında artış gösterdi $(P<0.001)$. CAT düzeyi TOE'nin verildiği gruplarda (TOE1, TOE2, PTOE1, PTOE2) kontrol grubuna göre artış gösterdi $(P<0.001)$. PARA grubunda CAT düzeyi istatistiksel olarak anlamlı oranda azaldı ( $<<0.001)$, PTOE1 ve PTOE2 gruplarındaki bu düzey PARA grubuna göre istatistiksel olarak anlamlı oranda arttı $(P<0.001)$. Sadece bitki ekstraktı uygulanan gruplarda SOD enzim düzeyi kontrol grubuna göre arttı $(P<0.001)$,
PARA grubundaki SOD düzeyi kontrol grubuna göre istatistiksel olarak anlamlı oranda azaldı $(P<0.001)$. GPx düzeyi TOE2, PTOE1 gruplarında kontrol grubuna göre bir artma söz konusu iken istatistiksel açıdan anlam tespit edilmedi ( $P>0.05)$. Nitrit düzeyi TOE1, TOE2, PTOE1, PTOE2 gruplarında kontrol grubuna göre bir artma ile birlikte, PARA grubunda istatistiksel olarak anlamlı oranda artış tespit edildi $(P>0.05)$. Kontrol grubuna göre karaciğer dokusu nitrat düzeyi TOE1, TOE2, PTOE1 arttı, PARA ve PTOE2 gruplarında anlamlı oranda artış görüldü $(P>0.05)$.

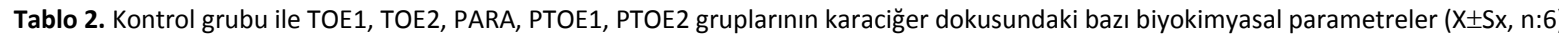

\begin{tabular}{|c|c|c|c|c|c|c|c|}
\hline & \multicolumn{7}{|c|}{ Gruplar } \\
\hline & Kontrol & TOE1 & TOE2 & PARA & PTOE1 & PTOE2 & $\mathbf{P}$ \\
\hline MDA (nmol/g) & $47.47 \pm 3.18^{c}$ & $65.02 \pm 3.24^{b c}$ & $86.08 \pm 2.44^{\mathrm{ab}}$ & $108.50 \pm 18.31^{\mathrm{a}}$ & $53.33 \pm 1.90^{c}$ & $58.80 \pm 5.24^{c}$ & $* * *$ \\
\hline GSH (mmol/g) & $0.43 \pm 0.03^{b c}$ & $0.41 \pm 0.04^{b c}$ & $0.60 \pm 0.04^{a}$ & $0.24 \pm 0.01^{d}$ & $0.34 \pm 0.06^{\mathrm{dc}}$ & $0.46 \pm 0.03^{b}$ & $* * *$ \\
\hline CAT (U/g) & $123.70 \pm 13.40^{\mathrm{bc}}$ & $239.88 \pm 36.24^{a}$ & $181.87 \pm 21.38^{b}$ & $102.65 \pm 4.41^{\mathrm{c}}$ & $155.11 \pm 8.67^{\mathrm{bc}}$ & $132.00 \pm 11.53^{b c}$ & $* * *$ \\
\hline SOD (EU/mg) & $7.32 \pm 0.29^{b}$ & $8.85 \pm 0.20^{\mathrm{a}}$ & $8.92 \pm 0.36^{\mathrm{a}}$ & $6.94 \pm 0.30^{\mathrm{bc}}$ & $7.39 \pm 0.35^{b}$ & $5.64 \pm 0.94^{c}$ & $* * *$ \\
\hline GPX (U/mg) & $10.51 \pm 0.85$ & $10.35 \pm 0.67$ & $11.20 \pm 0.54$ & $9.27 \pm 0.68$ & $1.70 \pm 0.59$ & $9.61 \pm 0.93$ & ÖS \\
\hline NіTRiT (ppm) & $12.48 \pm 1.04^{\mathrm{b}}$ & $12.92 \pm 0.73^{b}$ & $12.51 \pm 0.57^{b}$ & $18.99 \pm 0.41^{\mathrm{a}}$ & $17.28 \pm 1.35^{a}$ & $18.51 \pm 0.71^{\mathrm{a}}$ & $* * *$ \\
\hline NITRAT (ppm) & $76.78 \pm 5.03^{d}$ & $93.42 \pm 1.03^{c d}$ & $89.60 \pm 3.33^{c d}$ & $121.20 \pm 6.56^{b}$ & $95.52 \pm 1.89^{c}$ & $140.99 \pm 10.49^{a}$ & $* * *$ \\
\hline
\end{tabular}

ÖS: $P>0.05, * P<0.05,{ }^{*} P<0.01, * * * P<0.001$ ve $a, b, c, d, e:$ Aynı sütunda farklı harfle gösterilen ortalamalar arası fark önemlidir.
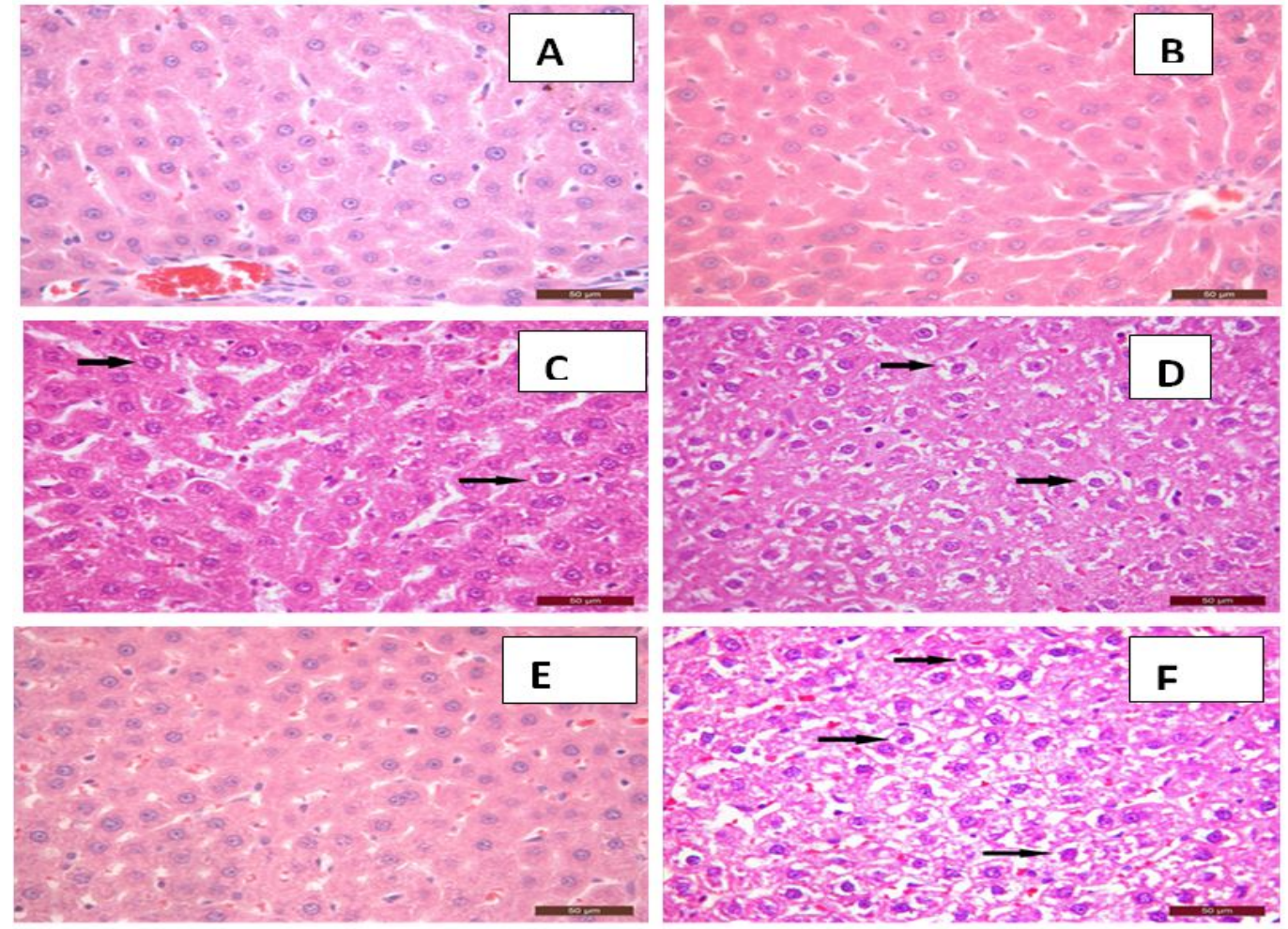

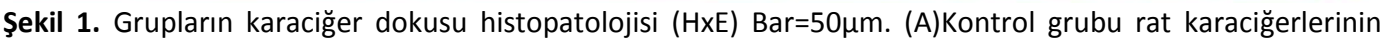
normal histolojik yapısı (HxE) Bar=50 $\mathrm{\mu m}$., (B) TOE1 grubu ratlarının karaciğerlerinin normal histolojik yapısı

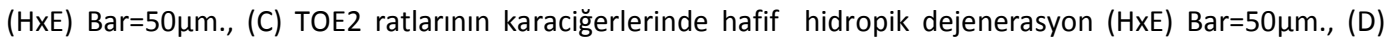
PARA grubu ratlarının karaciğerlerinde şiddetli hidropik dejenerasyon (HxE) Bar=50 $\mu$ m., (E) PTOE1 grubu ratlarının karaciğerlerinde çok hafif hidropik dejenerasyon (HxE) Bar=50 $\mu \mathrm{m}$., (F) PTOE2 grubu ratlarının karaciğerlerinde çok şiddetli hidropik dejenerasyon (HXE) Bar=50 $\mu \mathrm{m}$.

Histopatolojik bulgular: Kontrol, TOE1 ve PTOE1 gruplarında bulunan ratların karaciğerleri makrosko- bik olarak koyu kahverenginde iken PARA, TOE2 ve PTOE2 gruplarındaki ratların karaciğerlerinin solgun, 
genişlemiş ve kenarları küt sonlandığı görüldü. Karaciğerin histopatolojik incelemelerinde kontrol grubu ratlarında karaciğerlerin normal histolojik yapıda olduğu gözlendi. TOE1 grubu ratlarının karaciğer hepatositlerinde kontrol grubu gibi normal histolojik yapıda olduğu gözlendi. TOE2 ratlarının karaciğer hepatositlerinde periportal bölgelerinde hafif bir hidropik dejenerasyon gözlendi. PARA grubu ratlarının karaciğerlerinde hepatositlerde şiddetli diffuz hidropik dejenerasyon ve yer yer nekrotik hücrelere rastlandı. PTOE1 grubu ratlarının karaciğerlerinde çok hafif bir hidropik dejenerasyon görüldü. PTOE2 grubu ratlarının karaciğerlerinde hidropik dejenerasyon çok şiddetli olduğu belirlendi.

\section{Tartışma ve Sonuç}

Parasetamol, asetoaminofen olarak bilinen analjezik ve antipiretik bir ilaçtır ve aşırı dozda alındığında hayvanlarda ve insanlarda hepatotoksisite ve nefrotoksisiteye neden olur (Vermeulen ve ark., 1992). Literatür verilerine göre modern tıbbın ilerlemesine ve hepatik hücrelerin rejenerasyonuna yardımcı ve karaciğeri koruyan ilaçların yaygın olmasına rağmen karaciğer hastalıklarını önlemede birçok bitki ekstraktı kullanılmaktır (Chattopadhyay, 2003). Dandelion kökleri karaciğer fonksiyonlarını desteklemekte, çeşitli dermotolojik ve sistemik bozukluklarda karaciğer fonksiyonunu arttırıcı ve detoksifikasyonunda kullanılan bir bitki türüdür (You ve ark., 2010). Karaciğer hasarı; karaciğer enzimleri ve oksidatif statü ile belirlenir. Karaciğer hasarının belirleyici enzimleri olması açısından önem taşıyan enzimler; AST, ALT ve ALP (Gonzalez ve ark., 2012). Parasetamol ya da başka bir toksik maddenin $\left(\mathrm{CCl}_{4}\right.$, etanol vb.) vücuda alınmasıyla $\mathrm{AST}$, ALT, ALP'deki önemli değişiklikler karaciğerin bütününde hasarın meydana geldiğini gösterir (Krishna ve ark., 2012). Parasetamolün oral olarak ratlara uygulanmasıyla karaciğer hasarını gösteren serum veya plazma AST, ALT, ALP enzim aktivitelerindeki önemli artış olarak kendini göstermiş bu düzeylerin toksikasyon grubu ile kontrol grubunun karşılaştırılmasında artışın söz konusu olması toksik etkisinin olduğunu ortaya koymuştur (Nahida ve ark., 2011; Parmar ve ark., 2010). Bu çalışmada da toksikasyon grubunda plazma AST, ALT, ALP seviyelerinin kontrol grubuna göre yükselmesi ve verilen bitki ekstraktı ile karaciğer enzim seviyeleri karaciğerin iyileşmesinden dolayı azalması önceki çalışmalar ile uyumludur.

Ratlarda parasetamol ile hepatoksisite oluşturulan çalışmalarda toksikasyon grubunun kontrol grubu ile karşılaştırılmasında MDA düzeyinde yükselme söz konusu olmuştur (Hoşbaş ve ark., 2011; Parmar ve ark., 2010; Sundaria ve ark., 2013). Parasetamolle toksik hepatit oluşturulmuş ratlarda plazma MDA düzeyi kontrol grubuna göre artış gösterirken karaciğer MDA düzeyi önemli oranda artış göstermiştir (Sundaria ve ark., 2013). Parasetamol ile oluşturulan toksik hepatitte plazma ve karaciğer MDA düzeylerinin arttığı gösterilmiştir (Raja ve Mol, 2010; Aktaş ve ark., 2013). Yapılan farklı çalışmalar antioksidan özelliğe sahip çeşitli bitkilerin hepatoprotektif özelliklerinden yararlanılarak karaciğer hasarını tedavi edip lipid peroksidasyonunu azalttığı yönündedir (Kim ve ark., 2009; Krishna ve ark., 2012; Parmar ve ark., 2009; Rang ve ark., 2011; You ve ark., 2010). Bu çalışmada da Taraxacum officinale'nin çiçek, gövde ve yapraklarından elde edilen etanol ekstraktının hepatotoksisiteyi ve lipid peroksidas-yonunu azalttığı saptanmıştır.

GSH; hidrojen peroksit, süperoksit radikalleri gibi radikal türleri uzaklaştırır ve membran protein tiyollerini korur. Hepatik mitokondrideki GSH tüketimi parasetamol ile oluşturulan hepatotoksisitedeki en önemli mekanizma olarak düşünülür. Parasetamol gruplarında indirgenmiş GSH seviyesinin tükenmesinin NAPQI ile GSH'ın konjugasyonundan oluşan merkapturik asitten ileri geldiği bildirilmiştir (Sumanth ve Rana, 2006). Parasetamol ile toksisite oluşturulan grup ile kontrol grubu karşılaştırıldığında toksisite grubunda GSH düzeyinin azaldığı saptanmıştır (Parmar ve ark., 2010). Çalışmalardaki plazma ve karaciğer GSH düzeylerinin toksikasyon grubunda azalması sunulan çalışma ile uyumludur. GPx (Glutatyonperoksidaz) oksitlenmiş glutatyonu indirgenmiş glutatyona dönüştürerek hidrojen peroksit uzaklaştırabilen ve kısmen hücre membranında bulunup selenyum içeren metaloenzimlerdendir (Jung ve Henke, 1996). Zhang ve ark. (1989)'nın çalışmasına göre karaciğer ve böbrekteki enzim aktivitesinin başka dokulara (beyin, kas) oranla daha fazla olduğunu saptamıştır. Bu çalışmada da Taraxacum officinale bitkisinin toprak üstü aksanından elde edilen etanol ekstraktının toksikasyon oluşturulan ratlara uygulanması sonucu plazma GPx düzeyinde istatistiksel açıdan $\mathrm{P}<0.05$ oranında anlam saptan-mıştır. Karaciğer GPx düzeyinde de istatistiksel olarak anlam saptanmamıştır.

CAT, zararlı hidrojen peroksidi su ve oksijene dönüştürür, yüksek oranda reaktif hidroksil radikalindan dokuları korur (Chance ve Greenstein, 1992). Hücrelerde oksidatif stres oluşturan parasetamoldeki $\mathrm{H}_{2} \mathrm{O}_{2}$ ve oldukça yüksek olan toksik metabolitlerin birikmesiyle enzim aktivitesinde azalma meydana gelir (Pauli-Magnus ve ark., 2005). Parasetamol uygulanan çalışmada hepatotoksisite oluşturulan gruplarda kontrol grubuyla karşılaştırıldığında CAT aktivitesinin düştüğü tespit edilmiştir (Parmar ve ark., 2010). Bu çalışmada da benzer 
sonuçlar elde edilmiş, plazma CAT düzeyinde artış saptanırken, karaciğer CAT düzeyinde kontrol grubuna göre azalma tespit edilmiştir. TOE 200 $\mathrm{mg} / \mathrm{kg}$ uygulanması CAT aktivitesini arttırarak parasetamol toksisitesinden karaciğeri koruyup aşırı miktarda serbest radikal birikimini önleyebileceği kanısına varılmıştır.

Dandelion yapraklarının su ekstresinin uygulandığı bir çalışmada CAT düzeyinin, Dandelion grubunda önemli derecede artması da bu çalışma ile örtüşmektedir (Cho ve ark., 2003). Bir başka çalışmada Taraxacum officinale'nin kök eksteresini 250-500 ve $750 \mathrm{mg} / \mathrm{kg}$ olmak üzere üç ayrı dozda uygulamasına rağmen karaciğer dokusunda GSH ve CAT düzeylerinde hiçbir grupta herhangi bir önem saptanmamıştır (Plant ve Karaj, 2010). Fakat bu çalışmada CAT düzeyi plazma ve karaciğerde $\mathrm{P}<0.001$ düzeyinde önemli bulunmuştur. Bunun sebebinin Taraxacum officinale köklerinin flavanoid ve antioksidan maddelerinden fakir olmasından kaynaklanabileceği söylenebilir. Szymonik-Lesiuk ve ark. (2003) çalışmasında $\mathrm{CCl}_{4}$ ile oluşturduğu toksisitede SOD düzeyi hafif bir yükselme ile birlikte önem saptanmamışken, Domitrovich ve ark. (2010)'na göre toksisite oluşturulan grup, kontrol grubuyla karşılaştırıldığı zaman serum SOD düzeyinde önemli derecede artış tespit edilmiştir. Yapılan çalışma çoğu araştırma ile benzer şekilde sonuçlanmış, karaciğer ve plazma SOD düzeylerindeki artışın $\mathrm{P}<0.001$ düzeyinde öneme sahip olduğu saptanmıştır.

Luteolin ve luteolin 7-O-glukozid'den oluşan iki flavonoid bileşiği Taraxacum officinale'nin etilasetat fraksiyonunda zengin olup nitrik oksit sentaz (INOS) enziminin uyarılmasını ve nitrik oksit üretimini baskılar (Hu ve Kitts, 2004). Colle ve ark. (2012)'nın araştırmasına göre farelerde Parasetamol ile oluşturulan toksik hepatitte Taraxacum officinale yaprakları 2.2-difenil-1-pikrilhidrazil ve nitrik oksit radikallerine karşı temizlemesinin yanında antioksidan aktivite göstermiştir. Bu çalışmada da nitrat ve nitrit değerleri için bu sonuçlara benzer sonuçlar bulunmuştur. Genel olarak toksikasyon grubunda kontrole göre bir yükselişin olduğu söz konusu iken TOE gruplarında bu değerlere göre bir düşüş söz konusu olmuştur.

Bu çalışmada histopatolojik olarak Al-Malki ve ark. (2013)'nın yaptığı çalışmalara çok benzer sonuçlar bulunmuştur. Dandelion yapraklarının su ekstraktının ( 0.5 ve $2 \mathrm{~g} / \mathrm{kg}$ ) kullanıldığı gruplarda bu ekstraktın hepatotoksisiteye karşı koruma sağladığı belirtilmiştir. Başka çalışmalarda da toksisite oluşturulan grupların kontrol grubu ile karşılaştırıldığında; hepatositlerde şişkinlik ve nekrozun gözlendiği rapor edilmiştir.
Sonuç olarak ratların karaciğerinde parasetamol ile toksikasyon oluşturarak antioksidan savunma sistemlerinin zayıflatılmasıyla Taraxacum officinale bitkisinin toprak üstü aksanından elde edilen etanol ekstraktının biyokimyasal parametreler ve histopatolojik bulgulara göre $200 \mathrm{mg} / \mathrm{kg}$ uygulanan miktarı parasetamol ile oluşturulan hepatotoksisite ve karaciğer üzerine olumlu etkilerinin olduğu; $T$. officinale ekstraktının $250 \mathrm{mg} / \mathrm{kg}$ uygulanan miktarı ise ratlar üzerinde toksik etki yaparak lipid peroksidasyonu arttırdığı, antioksidan enzim düzeylerini önemli oranda azaltması nedeniyle toksik etkisinin olduğu belirlendi. Elde edilen ekstraktın biyokimyasal ve histopatolojik parametreler üzerine etkilerinin tesbiti literatüre öncül çalışma olarak sunulurken karaciğerdeki hasarı düzeltmek için ekstraktın farklı sürelerde ve yan etki oluşturmaksızın en iyi sonucu verecek farklı dozlarının da kullanılarak etkilerinin belirlenmesi konusunda yeni araştırmalara ihtiyaç olduğu kanaatine varıldı.

\section{Kaynaklar}

Adam B, 2012: Yiğitoğlu R. Tıbbi Biyokimya, 1. Baskı. İstanbul, Nobel Tıp Kitabevi, 189-249.

Aktaş Ö, Eskiocak S, Özgün GS, Yalçın Ö, Süt N, 2013: Asetaminofen ile toksik hepatit oluşturulan ratlarda L-karnitinin etkisi. Turkish Journal of Biochemistry/Türk Biyokimya Dergisi, 38, 475-482.

Al-Malki Abdulrahman L, Abo-Golayel MK, 2013: Hepatoprotective Efficacy of Chicory alone or combined with Dandelion leaves against induced liver damage. Life Science Journal, 10(4), 140-157.

Albayrak A, 2013: Serotonin-7 reseptörlerinin parasetamol ile indüklenen deneysel karaciğer toksisistesindeki yeri ve önemi. Türk Farmakoloji Derneği Farmakoloji Eğitiminde Kuşaklararası Bilimsel Etkileşme Seminerleri Programı, Bursa.

Anonim, 2013a: http://www.naturalfoodbenefits.com /display.asp?CAT=2\&l=120. Natural food benefits, Erişim tarihi; 20.09.2013.

Anonim,2013b:http://www.naturallifemagazine.com/120 4/dandelions.htm. Natural life magazine, Erişim tarihi; 20.09.2013.

Ball CR, 1996: Estimation and identification of thiols in rat spleen after cysteine or glutathione treatment pelevance to protection against nitrojen mustards. Biochemical Pharmacology, 15, 809-816.

Champe PC, Harvey RA, Ferrier D, 2007: Lippincott's Illustrated Reviews: Biochemistry. Çeviri: Ulukaya E. Biyokimya, 3. Baskı, İstanbul, Nobel Tıp Kitabevi.

Chance B, Greenstein DS, 1992: The mechanism of catalase actions-steady state analysis. Archives of Biochemistry and Biophysics, 37, 301-339.

Chattopadhyay RR, 2003: Possible mechanism of hepatoprotective activity of Azadirachta indica leaf extract: part II. Journal of Ethnopharmacol, 89, 217219. 
Cho SY, Oh YJ, Park J, 2003: Effect of dandelion (Taraxacum officinale) leaf extracts on hepatic antioxidative system in rats fed high cholesterol diet. Journal of the Korean Society of Food Science and Nutrition, 2, 458-463.

Colle D, Arantes LP, Gubert P, Luz SCA, Athayde ML, Rocha JBT, Soares FAA, 2012: Antioxidant properties of Taraxacum officinale leaf extract are involved in the protective effect against hepatoxicity induced by acetaminophen in mice. Journal of Medicinal Food, 15, 549-556.

Davis PH, 1965: Flora of Turkey and The East Aegea Islands, Edinburg, The University Press.

Domitrović R, Jakovac H, Romić Ž, Rahelić D, Tadić Ž, 2010: Antifibrotic activity of Taraxacum officinale root in carbon tetrachloride-induced liver damage in mice. Journal of Ethnopharmacology, 130, 569577.

Fernandez V, Videla LA, 1981: Effect of acute and chronic ethanol ingestion on the content of reduced glutathione of varios tissues of the rat. Experientia, 37, 392-394.

Fortea MI, Lopez-Miranda S, Serrano-Martinez A, Carreno BJ, Nunez-Delicado E, 2009: Kinetic characterisation and thermal inactivation study of polyphenol oxidase and peroxidase from table grape (Crimson Seedless). Food Chemistry, 113, 1008-1014.

Gallaher RN, Gallaher K, Marshall AJ, 2006: Mineral analysis of ten types of commercially available tea. Journal of Food Composition and Analysis, 19, 5357.

Gonzalez-Castejon M Visioli F, Rodriguez-Casado A, 2012: Diverse biological activities of dandelion. Nutrition Reviews, 70, 534-547.

Goth L, 1991: A simple method for determenation of serum catalase activity and revision of serum catalase activity and revision of reference range. Clinica Chimica Acta, 196, 143-152.

Hoşbaş S, Hartevioğlu A, Pekcan M, Deliorman Orhan D, 2011: Assessment of hepatoprotective activity of Achillea biebersteinii ethanol extract on carbon tetrachloride-induced liver damage in rats. FABAD Journal of Pharmaceutical Sciences, 36, 33-39.

Hu C, Kitts DD, 2004: Luteolin and luteolin-7-O-glucoside from dandelion flower suppress iNOS and COX-2 in RAW264.7 cells. Molecular and Cellular Biochemistry, 265, 107-113.

Jaeschke H, Bajt LM, 2006: Intracellular signaling mechanisms of acethominophen-induced liver cell death. Toxicological Sciences, 89, 31-41.

Jung K, Henke W, 1996: Developmental changes of antioxidant enzymes activity in kidney and liver from rats. Free Radical Biology and Medicine, 20, 613-617.

Kayaalp O, 2005: Analjezikler: Tıbbi Farmakoloji. İçinde: Lippincott: Analgesic Application, 7.Baskı, Ankara, 223-245.

Kim MY, Cheong SH, Kim MH, Son C, Yook HS, Sok DE, Cho JHK, ChunH, Kim MR, 2009: Leafy vegetable mix supplementation improves lipid profiles and antioxidant status in C57BL/6J mice fed a high fat and high cholesterol diet. Journal of Medicinal Food, $12,877-884$.
Koç H, 2002: Doğrudan, doğadan bitkilerle sağlıklı yaşama. Gaziosmanpaşa Üniversitesi Ziraat Fakültesi Tarla Bitkileri Bölüm Yayını, Tokat, Ümit Ofset.

Kordali Ş, Çakır A, Akcin TA, Mete E, Akcin A, Aydın T, Kılıç $H, 2009$ : Antifungal and herbicidal properties of essential oils and $n$-hexane extracts of Achillea gypsicola Hub-Mor. and Achillea biebersteinii Afan. (Asteraceae). Industrial Crops and Products, 29, 562-570.

Krishna A, Chaitanya D, Siva RC and Manohar RA, 2012: Hepatoprotective effect of biherbal ethanolic extract against paracetamol-induced hepatic damage in albino rats. Journal of Ayurveda and Integrative Medicine, 198.

Kuntz E, Kuntz HD, 2008: Hepatology Textbook and Atlas, $3^{\text {rd }}$ ed. Germany, Springer Press.

Matkovics B, Szabo L, Varga IS, 1988: Determination of enzyme activities in lipid peroxidation and glutathione pathways. Laboratoriumi Diagnosztika, $15,248-249$.

Nahida T, Qazi MA, Shah A, 2011: Curative activity of ethanol extract of Taraxacum officinale weber. against $\mathrm{CCl}_{4}$ induced hepatocellular damage in albino rats. Journal of Pharmacy Research, 4,3, 687689.

Parmar SR, Dave GS, Patel HV, Kıran K, 2009: HepatoProtective value of some plants extract against carbon tetrachloride toxicity in male rats. Journal of Cell and Tissue Research, 9, 1737-1743.

Parmar SR, Vashrambhai PH, Kalia K, 2010: Hepatoprotective activity of some plants extract against paracetamol induced hepatotoxicity in rats. Journal of Herbal Medicine and Toxicology, 4, 101106.

Pauli-Magnus C, Stieger B, Meier Y. Kullak-Ublick GA, Meier PJ, 2005: Enterohepatic transport of bile salts and genetics of cholestasis. Journal of Hepatology, 43, 342-357.

Placer ZA, Cushman LL, Johnson BC, 1966: Esimaion of product of lipid peroxidaion (malonyl dialdehyde) in biochemical systems. Analytical Biochemistry, 16, 359-364.

Plants A and Karaj I. The effects of Taraxacum officinale $L$. and Berberis vulgaris L. root extracts on carbon tetrachloride induced liver toxicity in rats. Journal of Medicinal Plants, 2010.

Raja B, Mol SD, 2010: The protective role of vanillic acid against acetaminophen induced hepatotoxicity in rats. Journal of Pharmacy Research, 1480.

Rang HP, Dale MM, Ritter JM, Flower RJ, Henderson G, 2011: Rang\&Dale's Pharmacology. $7^{\text {th }}$ ed. Elsevier Churchill Livingston, An imprint of Elsevier Ltd., Spain, 698-709.

Sigstedt SC, Hooten CJ, Callewaert MC, Jenkins AR, Romero $A E$, Pullin MJ, Kornienko A, Lowrey TK, Slambrouck SV, Steelant WF, 2008: Evaluation of aqueous extracts of Taraxacum officinale on growth and invasion of breast and prostate cancer cells international journal of oncology. International Journal of Oncology, 32, 1085-1090.

Stahr HM, 1977: Analytical Toxycology Methods Manual. Ames-lowa, USA, lowa State Univ. Press. 
Sumanth M, Rana AC, 2006: In vivo antioxidant activity of hydroalcoholic extract of Taraxacum officinale roots in rats. Indian Journal of Pharmacology, 38, 54.

Sun Y, Oberley LW, Li Y, 1988: A simple method for clinical assay of superoxide dismutase. Clinical Chemistry, 34, 497-500.

Sundaria K, Karthik D, llavenil S, Kaleeswaran B, Srigopalramd S, Ravikumar S, 2013: Hepatoprotective and proteomic mechanism of Sphaeranthus indicus in paracetamol induced hepatotoxicity in wistar rats. Food Bioscience, 5765.

Sümbüloğlu V, Sümbüloğlu K, 1998: Sağlık Bilimlerinde Araştırma Yöntemleri. 2. Baskı. Ankara, Hatiboğlu Yayınları.

Szymonik-Lesiuk S, Czechowska G, Stryjecka-Zimmer M, Slomka M, Maldro A, Celinski K, Wielosz M, 2003: Catalase, superoxide dismutase, and glutathione peroxidase activities in various rat tissues after carbon tetrachloride intoxication. Journal of Hepato-Biliary-Pancreatic Surgery, 309-315.

Tietze F, 1969: Enzymic method for quantitavite determination of nanogram amounts of total and oxidized glutathione. Analytical Biochemistry, 27, 502-522.

Vermeulen NPE, Bessems JGM, Vandestreat R, 1992: Molecular aspects of paracetamolinduced hepatotoxicity and it mechanism based prevention. Drug Metabolism Reviews, 24, 367-407.
Yoshioka T, Kawada K, Shimada T, 1979: Lipid peroxidation in materyal and cord blood and prodective mechanism against activated-oxygen toxicity in the blood. American Journal of Obstetrics and Gynecology, 135, 372-376.

You Y, Yoo S, Yoon HG, Park J, Lee YH, Kim S, Oh KT, Lee J, Cho HY, Jun W, 2010: In vitro and in vivo hepatoprotective effects of the aqueous extract from Taraxacum officinale (dandelion) root against alcohol induced oxidative stress. Food and Chemical Toxicology, 48, 1632-1637

Zhang L, Maiorino M, Roveri A, Ursini F, 1989: Phospholipid hydroperoxide glutathione peroxidase: specific activity in tissues of rats of different age and comparison with other glutathione peroxidases. Biochim Biophys Acta, 1006, 140-143.

**: Bu çalışma Yüksek Lisans tezinden özetlenmiş olup, çalışmanın özeti 7. Ulusal Veteriner Biyokimya ve Klinik Biyokimya Kongresinde poster olarak sunulmuştur

*Yazışma Adresi: Betül APAYDIN YILDIRIM Atatürk Üniversitesi, Veteriner Fakültesi, Biyokimya Anabilim Dalı, Erzurum, Türkiye. e-mail: betul_apaydin@hotmail.com 